\title{
Improved Biocompatibility of Titanium-Zirconium (Ti-Zr) Alloy: Tissue Reaction and Sensitization to Ti-Zr Alloy Compared with Pure Ti and $\mathrm{Zr}$ in Rat Implantation Study
}

\author{
Yoshiaki Ikarashi ${ }^{1}$, Kazuhiro Toyoda ${ }^{2, *}$, Equo Kobayashi ${ }^{3}$, Hisashi Doi ${ }^{3}$, \\ Takayuki Yoneyama ${ }^{3}$, Hitoshi Hamanaka ${ }^{3}$ and Toshie Tsuchiya ${ }^{1}$ \\ ${ }^{1}$ Division of Medical Devices, National Institute of Health Sciences, Tokyo 158-8501, Japan \\ ${ }^{2}$ Division of Pathology, National Institute of Health Sciences, Tokyo 158-8501, Japan \\ ${ }^{3}$ Department of Metallurgy, Division of Biomaterials, Institute of Biomaterials and Bioengineering, \\ Tokyo Dental and Medical University, Tokyo 101-0062, Japan
}

Titanium-zirconium (Ti-Zr) binary alloy has better corrosion resistance and mechanical properties than commercially pure Ti. The present study was designed to determine the biocompatibility of Ti-Zr alloy by an implantation test in animal bodies in comparison with pure Ti, Zr, and chromium (Cr) implants as positive controls. Sample specimens were placed in a subcutaneous position in rats for 8 months. No significant decreases in body weight, the weight of any organ, or the weight of any organ relative to body weight were found in the implant groups compared to a no-implant control group. On hematological examination, small differences in several parameters were found in some groups, but these changes were not attributable to the materials implanted. Mitogen-induced blastogenesis was observed in similar degrees among all implant groups. These results suggest that the implantation of test samples did not cause systemic toxicity or a decrease in immune activity. The fibrous capsule membranes around the $\mathrm{Ti}$ and $\mathrm{Ti}-\mathrm{Zr}$ alloy implants were thinner than those around $\mathrm{Cr}$ implants. The numbers of macrophages, inflammatory cells, and other cells involved in immune responses in and around the fibrous capsules of the $\mathrm{Cr}$ - and $\mathrm{Ti}$-implant groups were higher than those of the Ti-Zr alloy- and Zr-implant groups. The Ti-Zr alloy had the lowest total score of tissue responses among the materials tested. None of the animals from the Ti-, Zr-, and Ti-Zr alloy-implant groups exhibited a skin reaction following exposure to Ti or Zr salt solutions. These results indicate the Ti-Zr alloy has better biocompatibility than Ti for use as an artificial surgical implant.

(Received April 28, 2005; Accepted August 31, 2005; Published October 15, 2005)

Keywords: titanium alloy, titanium, biocompatibility, inflammation, hypersensitivity

\section{Introduction}

Stainless steel and cobalt-chromium (Co-Cr) alloys have been widely used as materials in orthopedic and dental implants because of their biocompatibility, physical properties, and manufacturing ease. ${ }^{1)}$ In general, these metallic alloys have excellent corrosion resistance and are not believed to cause any local or systemic responses. However, fretting corrosion of metallic implants is sometimes observed in contact with biological systems, causing the release of metallic ions from the implants. ${ }^{2,3)}$ Elevated levels of metal ions have been found in blood, urine, and tissues of patients and animals that have received metal implants. ${ }^{2-6)}$ Metallic ions, such as nickel (Ni), $\mathrm{Co}$, and $\mathrm{Cr}$, are known to cause adverse tissue reactions and allergy. ${ }^{7-13)}$

Titanium (Ti) and its alloys are currently considered the most attractive metallic materials for orthopedic and dental surgery. The use of $\mathrm{Ti}$ alloys is increasing due to their excellent mechanical strength, corrosion resistance, and good biocompatibility. ${ }^{14-17)}$ These properties are attributable mainly to the formation of a stable titanium oxide $\left(\mathrm{TiO}_{2}\right)$ layer on the surface. ${ }^{18,19)}$ However, the mechanical/tensile strength of commercially pure $\mathrm{Ti}$ is insufficient for its use as an artificial hip joint, pin, or screw, ${ }^{20)}$ and its wear resistance is also inferior to that of stainless steels and $\mathrm{Co}-\mathrm{Cr}$ alloys. ${ }^{20)}$ The appearance of increased wear debris from Ti has been associated with inflammation, bone resorption, and pain. ${ }^{18,19,21-24)}$ To improve mechanical strength and wear resistance, various elements have been added to create new

*Present address: Japan Tabacco Inc., Tokyo 130-8603, Japan
Ti alloys. Ti-6Al-4V alloy is a high-strength Ti alloy, but its biocompatibility is considered lower than that of commercially pure $\mathrm{Ti}$. The wear resistance and corrosion resistance of $\mathrm{Ti}-6 \mathrm{Al}-4 \mathrm{~V}$ alloy are inferior to those of $\mathrm{Ti}$, and $\mathrm{Ti}-6 \mathrm{Al}-$ $4 \mathrm{~V}$ alloy releases compounds and wear debris containing vanadium (V) or $\mathrm{V}$ ion, both of which are toxic. ${ }^{18)}$ At present, it is difficult to avoid the wear and/or fretting of implanted alloys in a living body, resulting in the release of elements contained in the alloy and the formation of wear debris. Therefore, it is preferable not to use highly toxic elements in alloys.

Zirconium ( $\mathrm{Zr}$ ) belongs to the VIa group in the periodic table, as does $\mathrm{Ti}$, and is known to have chemical properties similar to those of $\mathrm{Ti}^{20)}$ An insoluble oxide is formed on the surface in the air, and the surface oxide composition (zirconia) influences corrosion behavior. There is general agreement that $\mathrm{Zr}$ compounds have no local or systemic toxic effects. ${ }^{25)}$ Based on this apparent lack of toxicity, Kobayashi et al. selected $\mathrm{Zr}$ as an alloying element to improve the properties of commercially pure $\mathrm{Ti}$, and prepared a $\mathrm{Ti}-\mathrm{Zr}$ binary alloy as a material for use in medical devices, such as artificial joints or bone plates. ${ }^{20)}$ The hardness of $\mathrm{Ti}-$ $50 \%$ (atom\%) $\mathrm{Zr}$ alloy is 2.5 times as large as that of commercially pure $\mathrm{Ti}$, suggesting the alloy's superior mechanical strength. ${ }^{20)}$

Besides mechanical properties, the biocompatibility of an alloy is important if it is to be used in implant devices. We previously observed that animals were sensitized to $\mathrm{Cr}$ by long-term implantation of corrosive $\mathrm{Cr}$ alloys. ${ }^{26)}$ The animal model is a prevalent tool in examining tissue responses to implant material. The present study examined the biocom- 
patibility of the Ti-Zr alloy compared with those of $\mathrm{Ti}$ and $\mathrm{Zr}$ by implantation tests using rats. Pure chromium $(\mathrm{Cr})$ was used as a positive control material. After 8 months' implantation to a subcutaneous position, the reaction of the tissue around the specimen was studied hematologically and histologically. Since cases of sensitization to pacemakers which are made of $\mathrm{Ti}$ have been reported, ${ }^{27,28)}$ we topically applied a metal salt solution to rats in order to detect hypersensitivity to the metal. Further, the in vitro proliferation of spleen lymphocytes was also measured to evaluate immune system activity.

\section{Materials and Methods}

\subsection{Test materials}

Specimens of $\mathrm{Ti}, \mathrm{Zr}$, Ti-Zr binary alloy (Ti containing 50 atom $\% \mathrm{Zr}$ ), and $\mathrm{Cr}$ were used. The preparation of these specimens was reported in detail by Kobayashi et al. ${ }^{20)}$ Briefly, the specimens were prepared from sponge Ti (>99.8 mass\% purity), $\mathrm{Zr}$ (>99.5 mass\% purity), and electrolytic $\mathrm{Cr}$ metal (>99.98 mass\% purity) by arc melting with a nonconsumable tungsten electrode on a water-chilled copper hearth under an ultra-high-purity argon atmosphere. To prevent the macroscopic composition gradient by insufficient mixing, ingots were turned over and re-melted at least five times. To minimize mechanical trauma during implantation, the specimens were prepared in the form of plates with a diameter of $14 \mathrm{~mm}$ and a thickness of $1 \mathrm{~mm}$, and were cut out from these button ingots using a silicon carbide wheel cutter. The plate specimens were polished mechanically to a mirror finish using emery paper (gradually finer, up to 600 grit) followed by $0.03 \mathrm{~mm}$ alumina paste. Each specimen was washed with $70 \%$ ethanol and ultra-pure water, and autoclaved.

\subsection{Animals}

Female F344/DuCrj rats, 5 weeks old, were obtained from Charles River Japan Inc. (Kanagawa, Japan) and randomized into five groups of six rats each. The animals were housed in air-conditioned facilities (temperature $23 \pm 2{ }^{\circ} \mathrm{C}$, relative humidity $55 \pm 5 \%$, light cycle $12 \mathrm{~h} /$ day). Diet (F-2, Funabashi Farm Co., Chiba, Japan) and water were available ad libitum throughout the experimental period. After a 1-week acclimation period, all animals were used in the implantation test. All animals were cared for according to the Japan animal rights act and the NIHS-Japan guidelines for the care and use of laboratory animals.

\subsection{Implantation procedure ${ }^{26,29)}$}

The animals were anesthetized with $50 \mathrm{mg} / \mathrm{kg}$ Nembutal (sodium pentobarbital, Dainabot Co., Ltd., Osaka, Japan) via intraperitoneal injection. After the induction of anesthesia, the hair on the back was shaved around the implantation site and the skin was sterilized by brushing with a $70 \%$ ethanol solution. An incision was made with scissors on the right side of the shaved back skin, and a specimen was inserted subcutaneously. Control animals were treated by a sham operation with no implantation. After the operation, the incision was sutured. During the experimental period, body weight and health conditions were monitored.

\subsection{Hematological and histological examination}

At the end of the experimental period, the animals were anesthetized with diethyl ether, and total blood (approximately $4-5 \mathrm{ml}$ ) was collected from the abdominal aorta. The hematological data, such as red blood cell count (RBC), hemoglobin concentration (HGB), hematocrit (HCT), mean cell volume (MCV), mean cell hemoglobin $(\mathrm{MCH})$, mean cell hemoglobin concentration (MCHC), platelet count (PLT), and white blood cell count (WBC), in the blood sample were measured by a fully automated blood cell counter (M-2000, TOA Medical Electronics Co., Ltd. [Today's Sysmex Co.], Hyogo, Japan). In addition, differentiation of white blood cells was examined using an automated hematology analyzer (MICROX HEG-120A, Omron Tateisi Electronics Co., Tokyo, Japan; Sysmex Co. is presently acquiring Omron's blood image analysis business). According to the common method, spleen, liver, kidney, and the tissue surrounding the specimen were excised from each sacrificed animal. These tissues, along with the specimen, were fixed in $10 \%$ formalin and embedded in paraffin. After the specimen was removed gently, the tissue was sectioned and stained with hematoxylin and eosin for microscopic examination. The histological sections were examined microscopically, and the tissue responses-i.e., the distributions of fibroblasts, neutrophils, eosinophils, macrophages, giant cells, lymphocytes, and plasma cells-in the fibrous capsule that formed around the specimen were recorded, as was the infiltration of inflammatory cells around the capsule. ${ }^{26,29)}$ The intensity of these histological items was ranked as $-=$ no frequency $(0),+=$ low frequency (1), $++=$ moderate frequency $(2)$ and $+++=$ high frequency (3). The total score for the eight items was derived. The thickness of the fibrous capsule that formed around the specimen was also measured by a micrometer. ${ }^{29)}$ The thickness was determined in the orthogonal direction of the boundary between the capsule and the hole left by the specimen, and expressed as a mean value of 10 spots. $^{29)}$

\subsection{Evaluation of sensitization response}

At 8 months after implantation, a $50 \mu \mathrm{l}$ aliquot of $2 \%$ titanium chloride $\left(\mathrm{TiCl}_{4}\right)$ in ethanol, $10 \%$ zirconium chloride $\left(\mathrm{ZrCl}_{4}\right)$ in $70 \%$ ethanol solution, or $0.02 \%$ potassium dichromate $\left(\mathrm{K}_{2} \mathrm{Cr}_{2} \mathrm{O}_{7}\right)$ in $25 \%$ ethanol solution was applied to the shaved skin of the back using a closed-patch dressing (Trii Pharmaceutical Co., Ltd., Tokyo, Japan) for $24 \mathrm{~h}$. Salt of each metal was used as an application chemical for the determination of skin reaction in the patch testing. ${ }^{26,30)}$ The challenge concentrations of metal salts were determined by a preliminary irritation test, and they were the maximum concentrations to not elicit responses in normal animals. An application vehicle for metal salts at each concentration was prepared to maximize the content of ethanol in water. The skin reactions of erythema and oedema were evaluated by visual assessment at $24 \mathrm{~h}$ after removing the closed-patch dressing.

After 8 months of implantation, the spleen was excised and placed on a sterile 200-mesh stainless steel gauge in a $35 \mathrm{~mm}$ plastic dish. After $2 \mathrm{ml}$ of Hanks' balanced salt solution (pH 7.4, Sigma-Aldrich Inc., St. Louis, MO, USA) was added to the dish, the spleen was crushed mechanically using 
Table 1 Body and organ weights of rats after implantation of each material for 8 months.

\begin{tabular}{|c|c|c|c|c|c|c|}
\hline \multirow{3}{*}{ Material } & \multicolumn{6}{|c|}{ Weight $(\mathrm{g})($ Mean $\pm \mathrm{SD}, \mathrm{n}=6)$} \\
\hline & \multirow{2}{*}{ Body } & \multirow{2}{*}{ Thymus } & \multirow{2}{*}{ Spleen } & \multirow{2}{*}{ Liver } & \multicolumn{2}{|c|}{ Kidney } \\
\hline & & & & & Right & Left \\
\hline \multicolumn{7}{|c|}{ Absolute weight } \\
\hline Control & $213.8 \pm 16.3$ & $0.085 \pm 0.009$ & $0.35 \pm 0.03$ & $5.15 \pm 0.47$ & $0.61 \pm 0.04$ & $0.62 \pm 0.04$ \\
\hline $\mathrm{Ti}$ & $223.7 \pm 20.7$ & $0.086 \pm 0.010$ & $0.39 \pm 0.01^{*}$ & $5.63 \pm 0.59$ & $0.65 \pm 0.05$ & $0.65 \pm 0.04$ \\
\hline $\mathrm{Ti}-\mathrm{Zr}$ & $221.0 \pm 12.4$ & $0.082 \pm 0.013$ & $0.37 \pm 0.01$ & $5.78 \pm 0.32 *$ & $0.64 \pm 0.03$ & $0.64 \pm 0.03$ \\
\hline $\mathrm{Zr}$ & $231.5 \pm 8.1^{*}$ & $0.091 \pm 0.013$ & $0.38 \pm 0.01^{*}$ & $5.30 \pm 0.39$ & $0.65 \pm 0.05$ & $0.64 \pm 0.05$ \\
\hline $\mathrm{Cr}$ & $227.7 \pm 7.4$ & $0.087 \pm 0.012$ & $0.38 \pm 0.02$ & $5.96 \pm 0.26^{* *}$ & $0.67 \pm 0.03^{*}$ & $0.65 \pm 0.04$ \\
\hline \multicolumn{7}{|c|}{ Relative weight (organ/body $\times 1000$ ) } \\
\hline Control & & $0.40 \pm 0.03$ & $1.66 \pm 0.19$ & $24.2 \pm 2.5$ & $2.88 \pm 0.16$ & $2.90 \pm 0.10$ \\
\hline $\mathrm{Ti}$ & & $0.39 \pm 0.03$ & $1.75 \pm 0.13$ & $25.2 \pm 1.8$ & $2.93 \pm 0.08$ & $2.92 \pm 0.20$ \\
\hline $\mathrm{Ti}-\mathrm{Zr}$ & & $0.37 \pm 0.05$ & $1.67 \pm 0.10$ & $26.2 \pm 0.7$ & $2.88 \pm 0.10$ & $2.92 \pm 0.10$ \\
\hline $\mathrm{Cr}$ & & $0.38 \pm 0.05$ & $1.69 \pm 0.12$ & $26.2 \pm 1.2$ & $2.94 \pm 0.09$ & $2.87 \pm 0.12$ \\
\hline
\end{tabular}

${ }^{*},{ }^{* *}$ : Significantly different from the control group $(\mathrm{p}<0.05, \mathrm{p}<0.01)$.

Table 2 Hematological data of rats implanted with alloys.

\begin{tabular}{|c|c|c|c|c|c|}
\hline \multirow{2}{*}{ Item } & \multicolumn{5}{|c|}{ Group } \\
\hline & Control & $\mathrm{Ti}$ & $\mathrm{Ti}-\mathrm{Zr}$ & $\mathrm{Zr}$ & $\mathrm{Cr}$ \\
\hline $\mathrm{RBC}\left(\times 10^{4} / \mathrm{ml}\right)$ & $812 \pm 27$ & $729 \pm 13^{*}$ & $765 \pm 24^{*}$ & $779 \pm 37$ & $769 \pm 16^{*}$ \\
\hline $\operatorname{HGB}(\mathrm{g} / \mathrm{dl})$ & $14.8 \pm 0.5$ & $13.6 \pm 0.2^{*}$ & $14.4 \pm 0.4$ & $14.6 \pm 0.6$ & $14.4 \pm 0.2$ \\
\hline $\mathrm{HCT}(\%)$ & $41.8 \pm 1.1$ & $38.2 \pm 0.8^{*}$ & $40.0 \pm 1.7$ & $40.3 \pm 1.8$ & $39.9 \pm 0.8^{*}$ \\
\hline MCV (fl) & $51.5 \pm 0.6$ & $52.4 \pm 0.4^{*}$ & $52.3 \pm 0.8$ & $51.7 \pm 0.3$ & $51.9 \pm 0.2$ \\
\hline $\mathrm{MCH}(\mathrm{pg})$ & $18.2 \pm 0.2$ & $18.7 \pm 0.3^{*}$ & $18.8 \pm 0.2^{*}$ & $18.8 \pm 0.2^{*}$ & $18.8 \pm 0.3^{*}$ \\
\hline $\mathrm{MCHC}(\mathrm{g} / \mathrm{dl})$ & $35.4 \pm 0.5$ & $35.6 \pm 0.7$ & $35.9 \pm 0.5$ & $36.4 \pm 0.2^{*}$ & $36.1 \pm 0.5^{*}$ \\
\hline $\operatorname{PLT}\left(\times 10^{4} / \mu 1\right)$ & $61.1 \pm 4.9$ & $65.8 \pm 5.7$ & $66.3 \pm 6.8$ & $70.8 \pm 3.1^{*}$ & $60.0 \pm 4.2$ \\
\hline $\mathrm{WBC}\left(\times 10^{2} / \mu \mathrm{l}\right)$ & $20.0 \pm 7.0$ & $14.0 \pm 2.0$ & $18.0 \pm 4.0$ & $19.0 \pm 6.0$ & $15.0 \pm 3.0$ \\
\hline \multicolumn{6}{|l|}{ Differential cell counts (\%) } \\
\hline Neutrophil-band & $0.5 \pm 0.7$ & $0.1 \pm 0.3$ & $0.3 \pm 0.5$ & $0.1 \pm 0.2$ & $0.1 \pm 0$ \\
\hline Neutrophil-segmented & $31.5 \pm 5.8$ & $34.4 \pm 7.7$ & $28.8 \pm 6.6$ & $28.9 \pm 3.8$ & $30.6 \pm 4$ \\
\hline Basophil & $0.0 \pm 0.0$ & $0.0 \pm 0.0$ & $0.0 \pm 0.0$ & $0.0 \pm 0.0$ & $0.0 \pm 0.0$ \\
\hline Eosinophil & $2.5 \pm 1.3$ & $2.2 \pm 1.3$ & $2.5 \pm 1.2$ & $1.3 \pm 0.8$ & $1.5 \pm 1$ \\
\hline Lymphocyte & $63.1 \pm 6.6$ & $61.3 \pm 6.7$ & $65.7 \pm 5.9$ & $67.8 \pm 3.6$ & $65.7 \pm 4$ \\
\hline Monocyte & $2.4 \pm 1.0$ & $2.1 \pm 1.3$ & $2.8 \pm 1.5$ & $1.9 \pm 1.3$ & $2.2 \pm 2$ \\
\hline
\end{tabular}

Data represent mean values $\pm S D(n=6)$.

* Significantly different from the control at $\mathrm{p}<0.05$.

a syringe, and spleen cells were released. The cell suspension was transferred into a $15 \mathrm{ml}$ tube, and the tube was centrifuged at $1200 \mathrm{rpm}$ for $5 \mathrm{~min}$ at $4{ }^{\circ} \mathrm{C}$. After the supernatant was removed, the cells were treated with $2 \mathrm{ml}$ of $0.83 \%$ ammonium chloride-tris solution $(\mathrm{pH} 7.65)$ for $5 \mathrm{~min}$ at $37^{\circ} \mathrm{C}$ for hemolysis. The cells were washed twice by centrifuge at $1200 \mathrm{rpm}$ for $5 \mathrm{~min}$ with Hanks' balanced salt solution and resuspended in RPMI-1640 culture medium (Nissui Pharmaceutical Co., Ltd., Tokyo, Japan) supplemented with $25 \mathrm{mM} N$-2-hydroxyethylpiperazine- $N$ '-2-ethanesulfonic acid, 100 units $/ \mathrm{ml}$ penicillin, $100 \mu \mathrm{g} / \mathrm{ml}$ streptomycin, and $10 \%$ fetal bovine serum. The cell suspensions $\left(5 \times 10^{5}\right.$ cells $\left./ 200 \mu \mathrm{l}\right)$ were seeded into 96-well culture plates (three wells per group) and cultured with $10 \mu \mathrm{l}$ of $10^{-8} \mathrm{~mol} / \mathrm{L} \mathrm{K}_{2} \mathrm{Cr}_{2} \mathrm{O}_{7}, 10^{-5} \mathrm{~mol} / \mathrm{L} \mathrm{TiCl}_{4}, 10^{-5} \mathrm{~mol} / \mathrm{L} \mathrm{ZrCl}_{4}$, or $5 \mu \mathrm{g} / \mathrm{mL}$ Con $\mathrm{A}$ and $9.25 \mathrm{KBq}\left[{ }^{3} \mathrm{H}\right]$ methyl thymidine $\left({ }^{3} \mathrm{HTdR}\right)$ for $48 \mathrm{~h}$ at $37^{\circ} \mathrm{C}$ in a humidified atmosphere of $5 \%$ $\mathrm{CO}_{2}$ in air. After incubation, the cells were collected from each well on a glass filter (Type Filter Mat 11731,
SKATRON Instruments AS, Lier, Norway) using an automatic cell harvester (Type 11025, SKATRON Instruments AS). The incorporation of ${ }^{3} \mathrm{HTdR}$ into cells (counts per minute, cpm) was determined by liquid scintillation counting (LSC-5101, Aloka Co. Ltd., Tokyo, Japan).

\section{Results}

\subsection{Body and organ weights}

After 8 months of implantation, no significant visual changes such as rust or cracks were found on the surface of any specimen. In all implant groups, no decreases in body and organ weights were found compared with the control group (Table 1). The body weight in the Zr-implant group was higher than that in the control group. The thymus, spleen, liver, and kidney of some animals in the implant groups weighed more than those of control animals. However, the organ weights relative to body weight were not significantly different from group to group. 


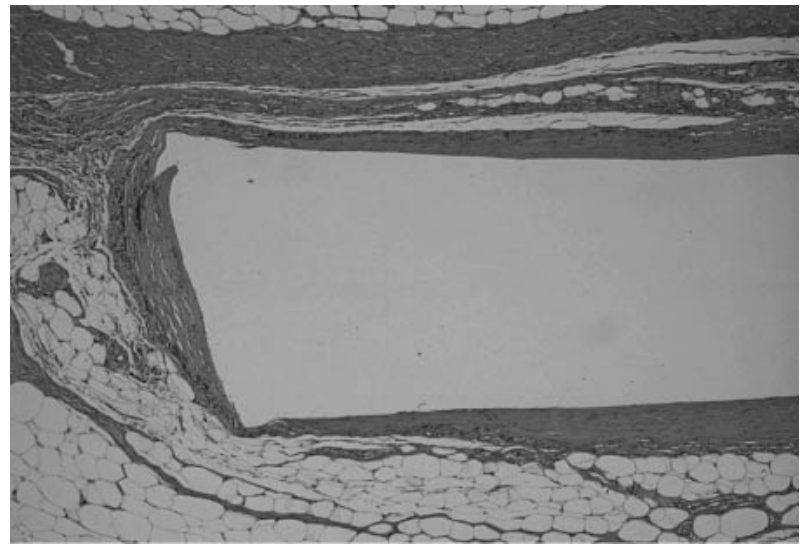

Fig. 1 Histological section of subcutaneous tissue around Ti (hematoxylin and eosin, original magnification $\times 16$ ). The central lumen was the site of the implant, and the tissue surrounding the lumen formed a fibrous capsule. The thickness of the fibrous capsule was expressed as the mean \pm standard deviation (SD) of 10 spots.

\subsection{Hematological examination}

Table 2 shows the results of analyses of blood constituents, such as RBC, PLT, and WBC counts, and HGB concentration. In the Ti-implant group, slight decreases in WBC count as well as HCT and HGB concentrations were found compared with the control group. Although some implant groups showed small changes in several parameters, none of the specimens showed a clear increasing or decreasing trend in any of these parameters. With regard to hematograms of WBC, no significant difference was found between the control and implant groups.

\subsection{Histological examination}

Figure 1 is a photograph of a histological section of tissue surrounding a $\mathrm{Ti}$ specimen. The central lumen was the specimen's extraction mark. Mature fibroblasts were found to form a distinct capsule between the soft tissue and the Ti specimen. Figure 2 is a typical image of tissues surrounding some specimens at high magnification $(\times 100)$. The lower part is the specimen's extraction mark. Two of the six animals in the Ti-implant group showed a moderate inflammatory response, and the image of animal no. 3 is shown in (a). Various types of cells infiltrated the fibrous membrane. The photograph in Fig. 3(b) is a tissue image of animal no. 7 of the Ti-Zr alloy-implant group. All animals in this group had levels of tissue reaction similar to those shown in Table 3(b). A fibrous capsule was formed, but the frequency of cell infiltration into the membrane around the $\mathrm{Ti}-\mathrm{Zr}$ alloy implant was lower than that with the other materials. In the Zr-implant group, the frequency of cell infiltration into the surrounding tissue was higher than that in the $\mathrm{Ti}-\mathrm{Zr}$ alloy-implant group but lower than that in the Tiimplant group (photograph not shown). The strongest tissue response was observed in the $\mathrm{Cr}$-implant group, and many inflammatory cells were present in the fibrous layer (photograph not shown).

Table 3 summarizes the histological findings of the tissue responses to each material. The distribution frequencies of inflammatory cells or fibroblasts in or around the fibrous capsule were ranked and the total score was derived for each (a)

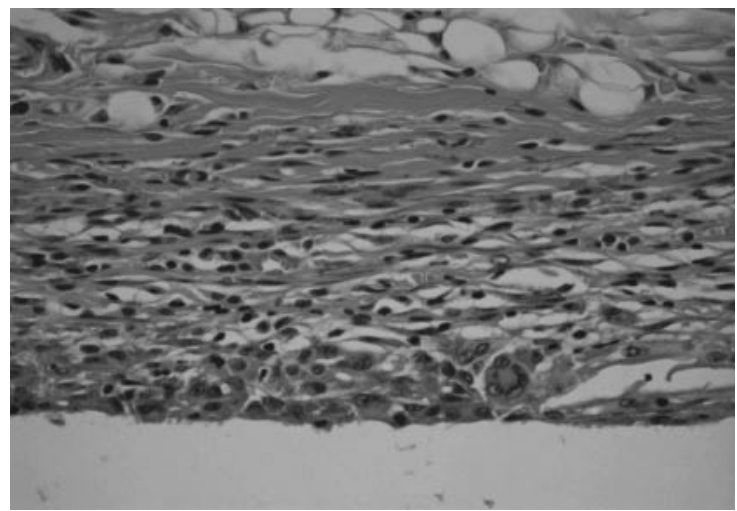

(b)

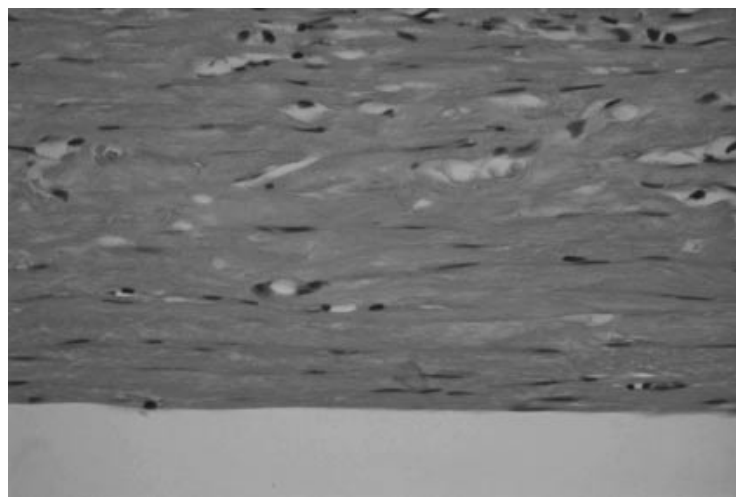

Fig. 2 Histological image of tissue around $\mathrm{Ti}$ (a) and $\mathrm{Ti}-\mathrm{Zr}$ alloy (b) at high magnification $(\times 100)$.

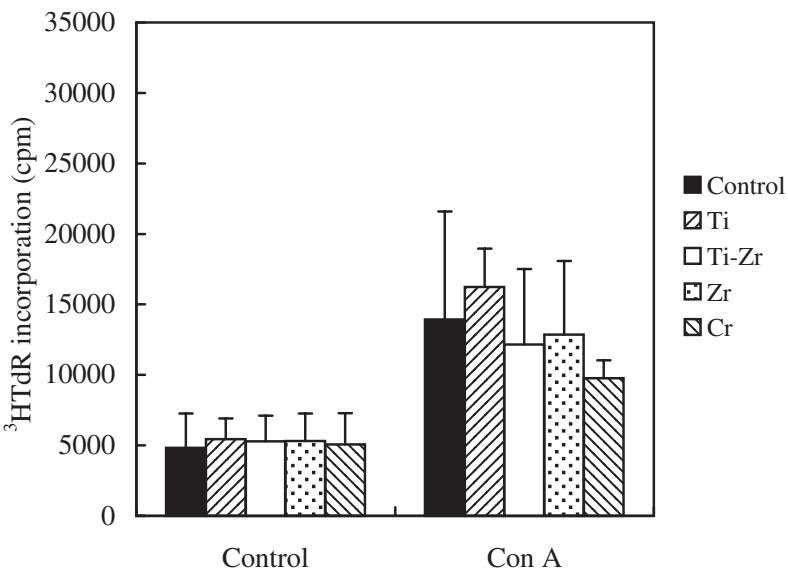

Fig. 3 Con A-induced blastogenesis of spleen lymphocytes in rats implanted with the material for 8 months. Single cell suspension of spleen cells $\left(5 \times 10^{5}\right.$ cells $)$ was cultured with $5 \mu \mathrm{g} / \mathrm{ml}$ Con $\mathrm{A}$ and $\left[{ }^{3} \mathrm{H}\right]$ methyl thymidine $\left({ }^{3} \mathrm{HTdR}\right)$ for $48 \mathrm{~h}$. The culture was terminated by automatic cell harvesting, and the ${ }^{3} \mathrm{HTdR}$ incorporation (cpm) was determined. The data are the mean \pm SD of 6 animals.

material. The cell distributions in tissues surrounding the materials observed in this study were not as strong as those in our previous implantation study, which used a 4-month experimental period. ${ }^{26)}$ Large amounts of fibroblasts were observed in all animals in the Cr-implant group and in some animals in the Ti-implant group. Greater numbers of macrophages, the main inflammatory cell types, infiltrated the fibrous capsules around the $\mathrm{Cr}$ or $\mathrm{Ti}$ specimens compared 
Table 3 Histological findings of the tissues around materials implanted for 8 months.

\begin{tabular}{|c|c|c|c|c|c|c|c|c|c|c|c|c|c|}
\hline \multirow{2}{*}{ Sample } & \multirow{2}{*}{ No. } & \multicolumn{7}{|c|}{ In fibrous capsule } & \multirow{2}{*}{$\frac{\text { Around fibrous capsule }}{\text { Inflammatory cells }}$} & \multirow{2}{*}{$\begin{array}{l}\text { Total } \\
\text { score }\end{array}$} & \multirow{2}{*}{\multicolumn{2}{|c|}{$\begin{array}{l}\text { Thickness of fibrous } \\
\text { capsule }(\mu \mathrm{m})\end{array}$}} & \multirow[b]{2}{*}{$($ mean $\pm \mathrm{SD})$} \\
\hline & & Fibroblasts & Neutrophils & Eosinophils & Macrophages & Giant cells & Lymphocytes & Plasma cells & & & & & \\
\hline \multirow[t]{6}{*}{$\mathrm{Ti}$} & 1 & +++ & + & + & ++ & + & ++ & +++ & ++ & 15 & $9 \pm 6$ & 83 & $119 \pm 48$ \\
\hline & 2 & + & + & + & + & - & + & - & + & 6 & & 71 & \\
\hline & 3 & +++ & ++ & + & +++ & ++ & +++ & ++ & +++ & 19 & & 80 & \\
\hline & 4 & + & + & - & + & - & + & - & + & 5 & & 170 & \\
\hline & 5 & ++ & + & - & + & - & + & - & + & 6 & & 179 & \\
\hline & 6 & + & - & - & + & - & + & - & + & 4 & & 129 & \\
\hline \multirow[t]{6}{*}{$\mathrm{Ti}-\mathrm{Zr}$} & 7 & + & + & - & + & - & + & - & + & 5 & $5 \pm 0$ & 119 & $128 \pm 16$ \\
\hline & 8 & + & + & - & + & - & + & - & + & 5 & & 121 & \\
\hline & 9 & + & + & - & + & - & + & - & + & 5 & & 140 & \\
\hline & 10 & + & + & - & + & - & + & - & + & 5 & & 108 & \\
\hline & 11 & + & + & - & + & - & + & - & + & 5 & & 153 & \\
\hline & 12 & + & + & - & + & - & + & - & + & 5 & & 126 & \\
\hline \multirow[t]{6}{*}{$\mathrm{Zr}$} & 13 & + & + & - & + & - & + & - & - & 4 & $5 \pm 1$ & 141 & $153 \pm 11$ \\
\hline & 14 & ++ & + & + & + & - & ++ & - & + & 8 & & 165 & \\
\hline & 15 & + & + & - & + & - & + & - & + & 5 & & 143 & \\
\hline & 16 & + & + & - & + & - & + & - & + & 5 & & 165 & \\
\hline & 17 & + & + & - & + & - & + & - & + & 5 & & 160 & \\
\hline & 18 & + & + & - & + & - & + & - & - & 4 & & 146 & \\
\hline \multirow[t]{6}{*}{$\mathrm{Cr}$} & 19 & +++ & ++ & +++ & ++ & - & +++ & - & ++ & 15 & $12 \pm 6$ & 222 & $170 \pm 36$ \\
\hline & 20 & +++ & + & ++ & ++ & - & ++ & - & + & 11 & & 161 & \\
\hline & 21 & ++ & + & + & + & - & ++ & - & ++ & 9 & & 167 & \\
\hline & 22 & +++ & +++ & ++ & +++ & + & +++ & +++ & +++ & 21 & & 198 & \\
\hline & 23 & ++ & + & - & + & - & + & - & - & 5 & & 118 & \\
\hline & 24 & + & + & ++ & + & - & ++ & - & + & 8 & & 155 & \\
\hline
\end{tabular}

Each parameter was scored as $-=$ no frequency $(0),+=$ low frequency $(1),++=$ moderate frequency $(2)$, and $+++=$ high frequency $(3)$. 
with the Ti-Zr or Zr specimens. A few giant cells were found in the Ti- and Cr-implant groups, but not in the Zr-implant and $\mathrm{Ti}-\mathrm{Zr}$ alloy-implant groups. Increased numbers of neutrophils, eosinophils, and lymphocytes were found especially in the Cr-implant group compared with the $\mathrm{Ti}-\mathrm{Zr}$ alloy- and $\mathrm{Zr}$-implant groups. The total scores in the $\mathrm{Ti}-\mathrm{Zr}$ alloy- and Zr-implant groups were significantly lower than that in the Cr-implant group.

The capsule membrane formed around the Ti specimen was thinner than those around the $\mathrm{Zr}$ and $\mathrm{Cr}$ specimens. Individuals varied considerably in membrane thickness in the Ti-implant group, so no statistically significant differences were obtained between the $\mathrm{Ti}$ - the $\mathrm{Ti}-\mathrm{Zr}$ alloy-implant group. The membrane around the $\mathrm{Cr}$ specimen was the thickest $(170 \pm 36 \mu \mathrm{m})$ among the materials tested and differed significantly from that around the $\mathrm{Ti}-\mathrm{Zr}$ alloy specimen $(126 \pm 16 \mu \mathrm{m})$. A statistical difference in membrane thickness was also found between the $\mathrm{Ti}-\mathrm{Zr}$ alloy- and the $\mathrm{Zr}$ implant groups.

\subsection{Sensitization}

A patch test was performed to assess the sensitization to each metal. The animals were topically challenged with $0.02 \% \mathrm{~K}_{2} \mathrm{Cr}_{2} \mathrm{O}_{7}, 2 \% \mathrm{TiCl}_{4}$, or $10 \% \mathrm{ZrCl}_{4}$ solution on the skin. None of the animals exhibited positive skin reactions to any of these metal salt solutions, so sensitization to $\mathrm{Cr}$, $\mathrm{Ti}$, or $\mathrm{Zr}$ did not develop as a result of implantation of the metal specimens.

Spleen lymphocyte proliferation is an in vitro indicator in the assessment of immune function and provides information useful for diagnosing contact allergy. The proliferation activity without mitogens or metal salts was similar among the test groups. The addition of $\mathrm{K}_{2} \mathrm{Cr}_{2} \mathrm{O}_{7}$ solution did not stimulate lymphocyte proliferation in the $\mathrm{Cr}$-implant group. In the same way, the stimulation index obtained by the addition of $\mathrm{TiCl}_{4}$ or $\mathrm{ZrCl}_{4}$ were almost all 1.0 in the Ti-, $\mathrm{Zr}$-, and $\mathrm{Ti}-\mathrm{Zr}$ alloy-implant groups (Table 4). Con A-induced blastogenesis was somewhat lower in the Cr-implant group than in the other groups, but no significant difference was observed (Fig. 3).

Table 4 Lymphocyte proliferative responses by stimulation with each metal salt.

\begin{tabular}{|c|c|c|c|}
\hline \multirow{2}{*}{ Sample } & \multicolumn{3}{|c|}{ Stimulation index (mean \pm SD) } \\
\hline & $\mathrm{TiCl}_{4} 10^{-6} \mathrm{~mol} / \mathrm{L}$ & $\mathrm{ZrCl}_{4} 10^{-6} \mathrm{~mol} / \mathrm{L}$ & $\mathrm{K}_{2} \mathrm{Cr}_{2} \mathrm{O}_{7} 10^{-9} \mathrm{~mol} / \mathrm{L}$ \\
\hline Control & $1.04 \pm 0.08$ & $1.03 \pm 0.06$ & $1.01 \pm 0.07$ \\
\hline $\mathrm{Ti}$ & $1.00 \pm 0.09$ & ND & ND \\
\hline $\mathrm{Ti}-\mathrm{Zr}$ & $0.98 \pm 0.03$ & $0.99 \pm 0.05$ & ND \\
\hline $\mathrm{Zr}$ & ND & $0.99 \pm 0.02$ & ND \\
\hline $\mathrm{Cr}$ & ND & ND & $0.97 \pm 0.05$ \\
\hline
\end{tabular}

Spleen was collected from each animal, and a single cell suspension of spleen cells was prepared. The cells $\left(5 \times 10^{5}\right.$ cells $)$ were cultured with each concentration of metal salt and $25 \mu \mathrm{Ci}\left[{ }^{3} \mathrm{H}\right]$ methyl thymidine $\left({ }^{3} \mathrm{HTdR}\right)$ for $48 \mathrm{~h}$, and the ${ }^{3} \mathrm{HTdR}$ incorporation $(\mathrm{cpm})$ into cells was determined. A stimulation index, the ratio of ${ }^{3} \mathrm{HTdR}$ incorporation relative to control wells, was derived for each metal salt. The data are mean \pm SD for 6 animals.

$\mathrm{ND}=$ not determined.

\section{Discussion}

In a corrosive environment, component elements of metallic materials are released from the surface as ions and chemical compounds, and some of them may cause local adverse tissue reactions and the development of metal allery. ${ }^{1,14)}$ Commercially pure $\mathrm{Ti}$ has generally good biocompatibility, ${ }^{14-17)}$ but its mechanical strength is insufficient for use in artificial hip joints. ${ }^{16,20)}$ Furthermore, the appearance of increased wear debris from $\mathrm{Ti}$ has been associated with tissue inflammation. ${ }^{1,2,31)}$ Elements for Ti alloys are classified into three microstructural categories: $\alpha$-stabilizers [aluminum (Al), oxygen $(\mathrm{O})$, nitrogen $(\mathrm{N})$, carbon $(\mathrm{C})$ ], $\beta$ stabilizers [molybdenum (Mo), vanadium (V), iron $(\mathrm{Fe}), \mathrm{Cr}$, $\mathrm{Ni}, \mathrm{Co}$ ] and neutral [zirconium $(\mathrm{Zr})$ ]. The properties of $\mathrm{Ti}$ alloys vary according to the composition of the elements. Ti alloys with $\alpha$ and near- $\alpha$ microstructures exhibit superior corrosion resistance but low ambient temperature strength. The $\alpha+\beta$ and $\beta$ alloys have high strength and good formability but relatively low corrosion resistance. ${ }^{18)}$ For example, Ti-6Al-4V alloy was developed as a high-strength material, but its low corrosion resistance in the living body was problematic. ${ }^{18)}$ Kobayashi et al. experimented with $\mathrm{Zr}$, whose chemical properties are similar to those of $\mathrm{Ti}$, and formed an insoluble oxide. They developed a $\mathrm{Ti}-\mathrm{Zr}$ alloy that has an $\alpha+\beta$ structure and better mechanical properties than commercially pure Ti. Because of its good mechanical properties, such as tensile strength and hardness, $\mathrm{Ti}-\mathrm{Zr}$ alloy was presented as a new biomedical material for use in artificial joints or bone plates. ${ }^{20)}$

Since orthopedic devices are generally implanted into a corrosive environment for anywhere from several months to the lifetime of the patient, long-term evaluation of biocompatibility is necessary. In a previous study, we investigated sensitization of the rat to $\mathrm{Cr}$ by implantation of $\mathrm{Cr}-\mathrm{Fe}$ alloys into a subcutaneous position for 4 months. ${ }^{26)}$ Lewin et al. also evaluated the local response to bone screws in guinea pigs after 4 months' implantation. ${ }^{32)}$ Oron and Alter examined the corrosion of metal specimens by implantation into rats for 14 months, and found progressive increase in corrosion concomitant with the length of implantation period. ${ }^{2)}$ In this study, an implantation period of 8 months was used because Ti-Zr alloy and other metal specimens do not easily corrode and release metallic ions. Furthermore, the early inflammatory responses caused by surgical injury could be disregarded.

The results of body or relative organ weights, hematological examination, and mitogen-induced blastogenesis suggest that the implantation of test materials did not cause systemic toxicity or decrease immune activity (Tables 1 and 2, Fig. 3). The membrane thickness around the $\mathrm{Cr}$ specimen was significantly higher than that around the $\mathrm{Ti}-\mathrm{Zr}$ alloy specimen (Table 3). The membranes that formed around the $\mathrm{Ti}-\mathrm{Zr}$ and $\mathrm{Ti}$ specimens were similar in thickness to that around the 316L-type stainless steel (SUS316L) specimen, which is used clinically. ${ }^{8,26)}$ Fibroblasts migrated to the injury site around the implants in the early phase and increased in density with an increasing amount of extracellular collagen. The tightly formed fibroblast membrane inhibits circulation of biological substances to inside the membrane, possibly 
with negative consequences. However, the membrane thickness is related only to fibroblasts but not to other cells, so it has debatable utility as an index of tissue response in implantation studies that cover long periods.

Local tissue response to a material is the most important aspect of the material's biocompatibility, and is mainly related to inflammatory reaction. ${ }^{15)}$ It can be evaluated by analyzing the cell population or the morphological characteristics of the tissue around the implant. ${ }^{8,21,22)}$ Ryhänen et al. found no qualitative differences in histology between stainless steel, Ti-6Al-4V, and Ti-Ni alloy 26 weeks after implantation in rats. ${ }^{8)}$ Macrophages are the main inflammatory cell types in a short-term implantation. They play an important role in acute inflammation and probably in determining the final biocompatibility of an implanted material. ${ }^{33,34)}$ They release various mediators that influence the activities of fibroblasts, lymphocytes, and other cells. ${ }^{33,34)}$ In addition, macrophages form multinucleated foreign-body giant cells, which constitute evidence of a specific inflammatory response evoked by a foreign substance. ${ }^{35)}$ Two of the six animals in the Ti-implant group showed a moderate inflammatory response. In all animals in the $\mathrm{Ti}-\mathrm{Zr}$ alloyimplant group, the frequency of cell infiltration into the membrane was smaller than in other implanted groups (Fig. 2). The numbers of macrophages and inflammatory cells in the fibrous tissue around the $\mathrm{Cr}$ and $\mathrm{Ti}$ specimens were higher than those around the $\mathrm{Ti}-\mathrm{Zr}$ and $\mathrm{Zr}$ specimens (Table 3). In the Ti- and Cr-implant groups, giant cells were found. These observations indicate that the $\mathrm{Cr}$ and $\mathrm{Ti}$ specimens induced inflammatory reactions more strongly than did the $\mathrm{Ti}-\mathrm{Zr}$ and $\mathrm{Zr}$ specimens. Neutrophils, eosinophils, and lymphocytes are involved in immune responses. ${ }^{8,36)}$ The infiltration frequency of these cells into the fibrous membrane was especially high in the Cr-implant group. A small increase in these cells was observed in the Tiimplant group relative to the control group. However, the number and type of infiltrating cells did not differ among the tested materials. The histological examination did not allow us to clearly say whether or not hypersensitive response occurred in an animal. The total scores obtained in the $\mathrm{Ti}-\mathrm{Zr}$ alloy- and Zr-implant groups were significantly lower than that in the Cr-implant group. The total score in the $\mathrm{Ti}-\mathrm{Zr}$ alloy-implant group was the same as or less than those of the Ti-implant and SUS316L-implant groups, the latter of which scored $7.3 \pm 1.5$ in the previous study. ${ }^{26)}$ These results suggest that the Ti-Zr alloy has good biocompatibility.

The patch test using metal salts is the most widely used method for evaluating metal allergy. ${ }^{30,37)}$ The in vitro lymphocyte proliferation test is also considered useful for assessing allergic conditions or immune activity. ${ }^{38,39)}$ If a positive reaction appears following the implantation of a metallic device, the contribution of the device to the development of metal sensitivity should be considered. We previously observed that animals became sensitized by the high amount of $\mathrm{Cr}$ ion released from the easily corrosive $\mathrm{Cr}-$ Fe alloy implanted in them.,26) The stable oxide complex layer that formed on the surfaces of $\mathrm{Ti}, \mathrm{Zr}$, and their alloys allowed little release of their ions. ${ }^{16,18,25)}$ Although highly unusual, cases of contact sensitivity to pacemakers which are made of Ti have been reported. ${ }^{27,28)} \mathrm{A}$ positive skin reaction to titanium chloride was obtained by a sensitization test using guinea pigs. ${ }^{38)}$ Topical exposure to Ti and $\mathrm{Zr}$ salt solutions in rats implanted with $\mathrm{Ti}, \mathrm{Zr}$, or $\mathrm{Ti}-\mathrm{Zr}$ alloy specimens resulted in no skin responses. $\mathrm{Ti}$ and $\mathrm{Zr}$ salts did not stimulate the proliferation of lymphocytes in these implanted animals (Table 4). None of these materials caused blastogenesis of spleen lymphocytes in the groups implanted with them (Fig. 3). These results indicated that the implantation of the $\mathrm{Ti}, \mathrm{Zr}$, and Ti-Zr alloy specimens did not induce sensitization to $\mathrm{Ti}$ or $\mathrm{Zr}$ ions. This may be explained by the weak sensitization potentials of $\mathrm{Zr}$ and $\mathrm{Ti}$ ions. Or it may be that the amount of ions released from each specimen was insufficient to cause a sensitization response.

As a result, the $\mathrm{Ti}-\mathrm{Zr}$ alloy and $\mathrm{Zr}$ had better biocompatibility than $\mathrm{Ti}$ and $\mathrm{Cr}$. Considering the fragility of $\mathrm{Zr}$, we concluded $\mathrm{Ti}-\mathrm{Zr}$ alloy as the best material tested in this study. For orthopedic implants, the hardness of metallic materials is important. However, for clinical application, other factors are more important: wear resistance, fretting corrosion resistance, and mechanical/tensile strength such as Young's modulus determine a material's suitability for the targeted position or tissue. In the future, we intend to design new alloys using a $\mathrm{Ti}-\mathrm{Zr}$ base to serve this purpose.

\section{Conclusion}

By implanting $\mathrm{Ti}, \mathrm{Zr}, \mathrm{Cr}$, or $\mathrm{Ti}-\mathrm{Zr}$ alloy into rats for 8 months, we evaluated the tissue response around the implant and the development of metal sensitization. There was no toxicological change in body or organ weights or in hematological parameters. The tissue inflammatory responses to the $\mathrm{Ti}-\mathrm{Zr}$ alloy were lower than those to $\mathrm{Ti}$. No sensitization response to the $\mathrm{Ti}-\mathrm{Zr}$ alloy appeared. The $\mathrm{Ti}-\mathrm{Zr}$ alloy has better biocompatibility than $\mathrm{Ti}$ for use as an artificial surgical implant.

\section{REFERENCES}

1) J. J. Jacobs, J. L. Gilbert and R. M. Urban: J. Bone. Jt. Surg. Am. 80 (1998) 268-282.

2) U. Oron and A. Alter: Clin. Orthop. Relat. Res. 185 (1984) 295-300.

3) S. Hierholzer, G. Hierholzer, K. H. Sauer and R. S. Paterson: Arch Orthop. Trauma Surg. 102 (1984) 198-200.

4) U. E. Pazzaglia, C. Minoia, L. Ceciliani and C. Riccardi: Acta Orthop. Scand. 54 (1983) 574-579.

5) T. Tsuchiya, Y. Ikarashi, T. Uchima, H. Doi, A. Nakamura Y. Ohshima, M. Fujimaki, K. Toyoda, E. Kobayashi, T. Yoneyama and H. Hamanaka: Mater. Trans. 43 (2002) 3058-3064.

6) L. Savarino, D. Granchi, G. Ciapetti, E. Cenni, M. Greco, R. Rotini, C. A. Veronesi, N. Baldini and A. Giunti: J. Biomed. Mater. Res. A. 66 (2003) 450-456.

7) A. McNamara and D. F. Williams: Biomaterials. 2 (1981) 33-40.

8) J. Ryhänen, M. Kallioinen, J. Tuukkanen, J. Junila, E. Niemelä, P. Sandvik and W. Serlo: J. Biomed. Mater. Res. 41 (1998) 481-488.

9) M. Uo, F. Watari, A. Yokoyama, H. Matsuno and T. Kawasaki: Biomaterials. 22 (2001) 677-685.

10) L. Kanerva, T. Sipilainen-Malm, T. Estlander, A. Zitting, R. Jolanki and K. Tarvainen: Contact Dermatitis. 31 (1994) 304-307.

11) W. R. Schriver, R. H. Shereff, J. M. Dommitz, E. F. Swintak and S. Civjan: Oral Surg. 42 (1976) 578-581.

12) D. Granchi, G. Ciapetti, L. Savarino, S. Stea, F. Filippini, A. Sudanese, R. Rotini and A. Giunti: Biomaterials. 21 (2000) 2059-2065.

13) L. Kanerva and L. Forstrom: Contact Dermatitis. 44 (2001) 103-104.

14) C. Schmidt, A. A. Ignatius and L. E. Claes: J. Biomed. Mater. Res. 54 
(2001) 209-215.

15) K. Yamaguchi, H. Konishi, S. Hara and Y. Motomura: Spine J. 1 (2001) 204-208.

16) C. E. Wen, Y. Yamada, K. Shimojima, Y. Chino, T. Asahina and M. Mabuchi: J. Mater. Sci. Mater. Med. 13 (2002) 397-401.

17) G. D. Krischak, F. Gebhard, W. Mohr, V. Krivan, A. Ignatius, A. Beck, N. J. Wachter, P. Reuter, M. Arand, L. Kinzl and L. E. Claes: Arch Orthop. Trauma Surg. 124 (2004) 104-113.

18) M. Long and H. J. Rack: Biomaterials. 19 (1998) 1621-1639.

19) J. O. Galante, J. Lemons, M. Spector, P. D. Wilson, Jr. and T. M. Wright: J. Orthop. Res. 9 (1991) 760-775.

20) E. Kobayashi, S. Matsumoto, H. Doi, T. Yoneyama and H. Hamanaka: J. Biomed. Mater. Res. 29 (1995) 943-950.

21) F. Katou, N. Andoh, K. Motegi and H. Nagura: J. Craniomaxillofac Surg. 24 (1996) 155-162.

22) D. F. Williams: J. Bone. Joint Surg. Br. 76 (1994) 348-349.

23) S. H. Lee, F. R. Brennan, J. J. Jacobs, R. M. Urban, D. R. Ragasa and T. T. Glant: J. Orthop. Res. 15 (1997) 40-49.

24) S. D. Rogers, D. W. Howie, S. E. Graves, M. J. Pearcy and D. R. Haynes: J. Bone. Joint Surg. Br. 79 (1997) 311-315.

25) C. Piconi and G. Maccauro: Biomaterials. 20 (1999) 1-25.

26) Y. Ikarashi, T. Tsuchiya, K. Toyoda, E. Kobayashi, H. Doi, T. Yoneyama and H. Hamanaka: Mater. Trans. 43 (2002) 3065-3071.

27) M. A. Peters, A. L. Schroeter, H. M. van Hale and J. C. Broadbent
Contact Dermatitis. 11 (1984) 214-222.

$28)$ P. A. Layor, P. A. Revell, A. B. Gray, S. Wright, G. T. Railton and M. A. Freeman: J. Bone. Joint Surg. 73 (1991) 25-28.

29) Y. Ikarashi, K. Toyoda, N. Ohsawa, T. Uchima, T. Tsuchiya, M. Kaniwa, M. Sato, M. Takahashi and A. Nakamura: J. Biomed. Mater. Res. 26 (1992) 339-356.

30) Y. Ikarashi, J. Momma, T. Tsuchiya and A. Nakamura: Biomaterials. 17 (1996) 2103-2108.

31) H. Benghuzzi: Biomed. Sci. Instrum. 32 (1996) 81-86.

32) J. Lewin, J. U. Lindgren and J. E. Wahlberg: J. Orthop. Res. 5 (1987) 604-608.

33) J. M. Anderson and K. M. Miller: Biomaterials. 5 (1984) 5-10.

34) D. G. Vince, J. A. Hunt and D. F. Williams: Biomaterials. 12 (1991) 731-736.

35) A. R. Murch, M. D. Grounds, C. A. Marshall and J. A. Papadimitriou: J. Pathol. 137 (1982) 177-180.

36) M. Thewes, R. Kretschmer, M. Gfesser, J. Rakoski, M. Nerlich, S. Borelli and J. Ring: Arch Orthop. Trauma Surg. 121 (2001) 223-226.

37) P. Thomas, B. Summer, C. A. Sander, B. Przybilla, M. Thomas and T. Naumann: Allergy. 55 (2000) 969-972.

38) S. Torgersen, O. T. Gilhuus-Moe and N. R. Gjerdet: Int. J. Oral Maxillofac Surg. 22 (1993) 246-250.

39) N. J. Hallab, K. Mikecz, C. Vermes, A. Skipor and J. J. Jacobs: Mol. Cell. Biochem. 222 (2001) 127-136. 